\title{
Intellectual Capital and Financial Performance in an Emerging Economy: An Empirical Investigation of a Nigerian Bank
}

Michael Chidiebere Ekwe*

\section{Abstract}

The general belief that employees of an organization are important assets to that organization has not been empirically proved as not many studies have investigated the relationship or association between the intellectual capital components and the organizational performance indices. More so, as these assets are not reported in the balance sheet, it makes it more difficult to convince researchers and decision makers that the intellectual capital base of a firm can positively and significantly affect the firm's financial performance. This study therefore investigates the role intellectual capital plays in a firm's financial performance and also contributes in filling the gap in literature. The value added intellectual coefficient (VAIC) model was used to measure the impact of the three types of capital on the performance of the bank. Data were collected from the annual reports of the bank and from the publications of the Nigeria Stock Exchange (NSE). The intellectual and physical capitals of the bank were analyzed and their effect on the bank's financial performance was measured using multiple regression analysis models. From the result of the analyses, it can be seen that there is a positive relationship between a bank's intellectual capital and its financial performance. It also showed that efficient utilization of

* Faculty of Management Sciences, Enugu State University of Science and Technology, Enugu, Nigeria; ekwemike@yahoo.com 
physical and intellectual capital leads to better performance.

Keywords: Intellectual capital, Financial performance, Employee productivity, Nigerian bank.

\section{Introduction}

In most companies today, intellectual capital (IC), rather than the traditional assets of land and equipment, forms the greater part of market value of firms. Over the years, physical capitals such as land, plant and equipment, etc have been seen as the major determinants of a firm's economic performance. However, with the emergence of science and technology as well as the latest globalisation, the ways these systems are run today have significantly been altered. The new system is driven by this newly discovered capitals- the intellectual capital. Under the new dispensation, knowledge, ability, skills, experience and attitude of workers, organizations use intellectual capital as a critical resource to enhance their performances. While companies in software manufacturing, finance, pharmaceutical, etc depend on their level of intellectual capital to earn revenue, production or manufacturing companies use Intellectual Capital with their physical assets to sharpen their competitive edge (Ahangar, 2011). Bornemann et al. (1999) also discovers that enterprises which have managed their intellectual capital better, had achieved stronger competitive advantage than the general enterprises. Also they reported that companies which had strengthened their own intellectual capital management compared to the others had performed better. Brennan and Connell (2000) also claim that intellectual capital management played an important role in the long-term business performance of an enterprise. Furthermore, it is argued that the inability of financial statements in explaining firm value is due to the fact that the source of economic value is no longer the production of material goods, but the creation of intellectual capital. Intellectual capital is defined as the possession of knowledge, experience, skills, good relationships, and technological capacities, which give organizations competitive advantage (Ahangar, 2011). Intellectual capital includes human 
capital and structural capital comprising customers, processes, databases, brands, and systems (Edvinsson \& Malone, 1997).

Intellectual capital has also been a subject of intense research in recent years in the developed world; the main focus of which is on specific industries. However, only a handful number of studies have focused on emerging economies like India, Nigeria, etc in evaluating the implications of intellectual capital in specific industries. The implications of intellectual capital are more prominent in the emerging economies as they have abundant human capital at their disposal (Kamath, 2007). With that in mind and considering the importance and the contributions of developing economies in the global economy, it is important to establish the impact of intellectual capital in a different sociopolitical and economic setting. In particular, this study will explore whether intellectual capital is efficiently utilized by banks in Nigeria to their advantage in enhancing their profitability.

The banking sector, in any country plays a pivotal role in setting the economy in motion and helps immensely in its development process. Banks promote growth and success of businesses in both developed and developing countries. According to Kamath (2007), the banking sector is an ideal area for IC research because the banking sector is "intellectually" intensive and its employees are (intellectually) more homogeneous than those in other economic sectors. Empirical evidence of the understanding and development of intellectual capital (IC) concepts in emerging economies is still at its infant stage (Firer \& Williams, 2003) and because emerging economies contribute significantly to the prosperity and stability of the world economy, there is a need to establish evidence of the development of intellectual capital in these economies.

Following from the above, the objective of this study is to examine the influence of intellectual capital on financial performance of banks in Nigeria. In particular, this study aims to examine empirically the association between a measure of intellectual capital, and the banks' financial performance. The study contributes to the literature by focusing on Nigeria rather than a developed Western economy, unlike most researches already available in the field of IC. 
The remaining of this paper is organized as follows. First, a review of literature is presented. The section discusses the definition of intellectual capital, reviews previous studies and presents the hypotheses. Next, there is a section discussing the research methods adopted in this study. It is followed by a presentation and discussion of the findings. Finally, the paper ends with a conclusion.

\section{Literature Review}

\section{Definition of intellectual capital}

According to Engstrom et al. (2003), there is no uniform definition of intellectual capital. When the word intellectual capital is mentioned, Ahangar 2011, suggests it includes general knowledge, design approaches, ideas, computer programs, inventions and publications. In a similar way, Ben-Simchon, (2005) describes 'intellectual capital' to include the non- tangible or non-physical assets and other resources of a firm, such as the practices, patents and the implicit knowledge of its members and their network of partners and contracts. Furthermore, Edvinsson and Malone (1997) describe IC as the possession of knowledge, applied experience, organizational technology, customer relations and professional skills that provide a company with a competitive edge in the market but Roos et al (1997) sees it as 'sum of knowledge of its members and practical translation of this knowledge into brands, trademarks and processes.' Stewart (1997), opines that intellectual capital is "something that cannot be touched, although it slowly makes you rich." He went on to describe intellectual capital to be 'packaged useful knowledge'. Sullivan (2000) suggests intellectual capital includes 'knowledge that can be converted into profit.' Saint-Onge's model of 1996 which was developed in the early 1990s divides intellectual capital into three parts as follows: Human capital, Structural capital, and Customer capital (Saint-Onge, 1996). It was one of the most popular models for identifying and classifying intellectual capitals. The model identified and recognized Human capital as the largest and the most important intangible business resource which gives the organisation a competitive edge. It also identified and recognized structural capital as the supportive infrastructure for human capital. 
Ahangar, 2011 further suggests that human capital produces the goods or services that customers require and also provides solutions to their problems. He concludes that human capital includes experiences, collective knowledge, skills, competency, the talents of management and employees within an organization, the organization's creative capacity as well as its ability to be innovative. Although investment in human capital is growing, there is still no standard measure to report its effectiveness in a firms' balance sheet today (Amah, 2006).

Structural capital as the supportive infrastructure for human capital-it is the capital which remains in the factory or office when the employees leave at the end of the day (Stewart, 1997). It includes processes, organizational ability, data and patents, etc. Unlike human capital, it is the company's property and can be traded, reproduced and shared by, and within the organization (Ahangar, 2011).

\section{How to measure intellectual capitals}

Despite the increasing recognition of intellectual capital in driving firm value and competitive advantages, there is no one acceptable measure of IC. According to Goh (2005), there are more than 20 methods of measuring intellectual capital. To name a few, they are market-to-book value, Tobin's ' $q$ ', Calculated Intangible Value (CIV), Balanced Scorecard (BSC), Economic Value Added (EVA), and Value Added Intellectual Coefficient (VAIC) proposed by Public. Of special interest is the VAIC, developed by Pulic Ante, which is a new management and control tool designed to enable an organization monitor and measure the intellectual capital performance and potential of a firm (Kamath, 2007). Instead of directly measuring the firm's intellectual capital, VAIC identifies, measures and reports the efficiency of value added (VA) by an organisation's intellectual ability. The major components of VAIC can be viewed from a firm's resource base-employed capital, human capital, and structural capital (Pulic, 2000). While employed capital is tangible by nature, human capital and structural capital are intangibles. Essentially, VAIC indicates the total efficiency of value creation from both tangible and intangible resources employed. Intellectual capital efficiency (ICE), which is part of 
VAIC, reflects the efficiency and effectiveness of value added by the human and structural capitals employed. VAIC is based on the belief that the better a company's resources are utilized, the higher the company's value creation efficiency will be (Kujansivu \& Lonnqvist, 2007).

\section{Influence of intellectual capital on corporate performance}

Several studies have adopted the VAIC model as the primary measurement of IC (Nazari \& Herremans, 2007). For instance, Chen et al. (2005) used VAIC to investigate the relationship between the firm's intellectual capital and market-to-book value ratios. They analyze whether intellectual capital contributes to the firm's financial performance and whether intellectual capital can be used as a leading indicator for future financial performance. Using all firms listed on the Taiwan Stock exchange (TSE) during 1992-2002, they found that the firm's market value and financial performance are positively associated with corporate intellectual ability. They also concluded that the intellectual capital may be an indicator for future financial performance.

With regard to bank performance and intellectual capital, there have been a number of researches that adopted VAIC to examine the influence of intellectual capital on the banks performance. Among other studies, Pulic (1997 \& 2002) measured intellectual capital performance of Austrian banks for the period 1993-1995 and Croatian banks for the period 1996-2000. He revealed significant differences in the banks ranking based on efficiency and performance. Goh (2005) conducted a study to measure the intellectual capital performance of commercial banks in Malaysia for the period from 2001 to 2003. He found that value creation capability of both domestic and foreign banks in Malaysia is largely attributed to human capital efficiency. The study concluded that the investment in human capital yields a relatively higher return than investment in the two other components of VAIC - physical and structural capital.

Yalama and Coskun (2007) tested the effect of intellectual capital performance on profitability of banks in Turkey for the period from 1995 to 2004. They concluded that IC is more important than 
physical capital for banks. Other studies that adopted VAIC in examining bank performance include the works of Mavridis (2004), and Mavridis and Kyrmizoglou (2005). Their findings are consistent with those found by Yalama and Coskun (2007).

In India, Kamath, (2007) estimated VAIC in measuring the valuebased performance of the Indian banking sector for a period of five years, from 2000 to 2004 . The study confirms the existence of vast differences in the performance of Indian banks in different segments. There is also an improvement in the overall performance over the study period. Also, (Kujansivu \& Lonnqvist, 2007) reported that Firer and Williams (2003) adopted the VAIC method to examine the relationship between intellectual capital and traditional measures of corporate performance, including profitability (returns on assets), productivity (turnover of total assets) and market value (market-to-book value ratio of net assets) in South Africa. Except that the capital employed efficiency had a significantly positive effect on the market value of firms, their empirical results failed to find any strong relationship among the three value-added efficiency components and the three dependent variables.

Also Davenport and Prusak (1998) noted that the technological advances in data processing, Communication and transportation, as well as customer demand and strategists' planning have made the world economy to change very fast. Again, Bontis et al (2000) conducted an investigation on the three elements of intellectual capital, which are: the human capital element, structural capital element and customer element, as well as their inter relationships. Their major discovery formed a conclusion that human and customer capital were both significant factors in the way in which businesses are run and that the structural capital has a positive influence on the organisation's financial performance. Saudah Sofia (2005) also examined the impact of the degree and form of intellectual capital on management accounting practices, especially on the performance measurement and corporate performance variables. The results suggest that intellectual capitals have significant effect on the corporate performance variables.

Teese (2000) also states that both the tangible and the intangible assets of the firm as well as the firm's intellectual capital are the 
keys factors to achieve sustainable competitive advantage and that these drive the economic growth of the firm(Drew, 1999).

Ahangar 2011 also reported that Riahi-Belkaoui (2003) tested the relationship between intellectual capital and the performance of selected multi-national companies in the USA and found from the result of the empirical analysis that intellectual capital was positively related with financial performance. Furthermore, Reed (2000) discovers that intellectual capitals are strong predictors and determinants of a firm's economic and social performance.

In all these studies, a very high positive relationship was discovered between economic performance variables and intellectual capital indices which are attributable to the efficient usage and management of human resources.

To sum up, the findings of previous studies are mixed. Most of these studies present evidence that there is a relationship between intellectual capital and the firm's financial performance. However, some studies such as that of Firer and Williams (2003) failed to find any strong association between intellectual capital and profitability. Therefore, there is a need to study further the relationship between intellectual capital and financial performance of banks in other countries since empirical evidence of the understanding and development of intellectual capital (IC) concepts in emerging economies is still in its infant stage (Firer and Williams, 2003). In addition, the banking industry in any economy is underpinned by cultural concerns, the legal system and its practices. Therefore, the findings of other studies may not be generalized to banks in Nigeria because they have been conducted in environments different from Nigeria.

\section{Development of hypotheses}

In line with the works reviewed above, an organisation can gain a competitive edge or advantage which culminates into a superior financial performance through the acquisition, holding and usage of the strategic capitals (Wernerfelt, 1984; Lev, 1987). Both tangible and intangible capitals are perceived as potential strategic assets to an organisation (Riahi \& Belkaoui, 2003). Included among the intangible assets or capitals is the intellectual capitals, which have been discovered to be a veritable instrument or assets which 8 
organisations can carefully exploit to gain competitive advantage in this modern knowledge economy. Agreeing to the above, Riahi and Belkaoui (2003) opine that intellectual capital means the specific and valuable knowledge that belongs to the organization. The idea of identifying intellectual capitals as strategic assets is based on the perceived characteristics that there is a link between IC on the one hand and an organisation's performance on the other hand (Seethamraju, 2000). According to Patton (2007) the productivity of a firm depends more on its intellectual capital and system capabilities (structural capitals) than on the physical assets. Bontis (2001) argues that leveraging knowledge assets is the key to a firm's prosperity. Furthermore, so many researchers now have the view that in comparison with the physical capital, the intellectual capitals are more likely to be the key resources for many organisations which help them in acquiring the required competitive advantage or, to ensure market dominance (Brernan \& Connell, 2000; Marr, 2004). Based on the studies above, it can be seen that the organisation with better intellectual capital ability or performance is expected to have higher rate of financial performance as evidenced in the organisations' profitability, higher productivity and higher growth in revenues. Thus, the researcher predicts a positive relationship between the financial performance as measured by profitability and the intellectual capital performance. Therefore, the hypotheses are:

H1: There is a relationship between components of value added intellectual coefficient (VAIC) and financial performance of banks in Nigeria.

The theoretical positive relationship between VAIC and financial performance of banks is supported by several studies such as Pulic (1997) in Austria, Pulic (2002) in Croatia, Goh (2005) in Malaysia, Mavridis (2004) in Japan, Mavridis and Kyrmizoglou, (2005) in Greece, and Kamath (2007) in India. As VAIC is composed of both the tangible resources efficiency (capital employed efficiency) and IC efficiency (human capital efficiency and structural capital efficiency), we subsequently test the following hypotheses:

$\mathrm{H} 2$ : There is a relationship between human capital efficiency and financial performance of banks in Nigeria. 
H3: There is a relationship between structural capital efficiency and financial performance of banks in Nigeria.

H4: There is a relationship between capital employed efficiency and financial performance of banks in Nigeria.

\section{Research Methods}

\section{Data}

There are twenty-four banks listed on the Nigeria Stock Exchange. However, due to the unavailability of the annual reports of four banks, only eighteen banks became the subjects of investigation. This study covers a three-year period, from 2005 to 2007; thus there are a total of 54 observations. The necessary data are obtained from the banks' annual reports. Since the data is audited, the measurement is objective and verifiable.

\section{Analysis}

Financial performance is the dependent variable in this study. Although there are several ways of measuring financial performances such as return on equity (ROE); in the case of marketbased and economic value added, we measure performances by the return on assets (ROA). According to Haniffa and Hudai (2006), a higher ROA indicates the effective use of the company's assets in serving shareholders economic interests. The ROA is used in this study because it provides a measure for assessing the overall efficiency with which firm assets are used to produce net income from operations (Miller et al., 2001). Moreover, Miller et al. (2001) argue that ROA reflects the management's effectiveness in deploying the capital, because it is certainly possible to be efficient and yet poorly positioned in terms of how capital is being utilized. The ROA, compared to other measures such as ROE, is appropriate for the banking industry because the latter does not take into consideration the financial risks of the bank's activities whereas the former does. Despite the argument that ROA is calculated based on profit figures that can be manipulated through earnings management (Dechow, 1994; DeFond \& Park, 1997; Dechow \& 10 
Skinner, 2000), we believe that ROA is a reasonable measure of profitability.

The value added intellectual coefficient- VAIC model developed by Public Ante in 1998 forms the basis for measuring the independent variables. The model is a composite sum of three separate indicators of different types of capital. The formal relationship is shown algebraically in the following equation:

$$
\mathrm{VAIC}=(\mathrm{CEE})+(\mathrm{HCE})+(\mathrm{SCE})
$$

The three indices of value added intellectual coefficient above are determined using the following equations:

$\mathrm{CEE}=$ Capital employed efficiency $=$ Value Added $(\mathrm{VA}) /$ Capital Employed (CE),

HCE = Human Capital Efficiency =Value Added (VA) / Human Capital (HC), and

SCE = Structural Capital Efficiency =Structural capital (SC) / Value added (VA)

Value added (VA) is calculated as follows:

$\mathrm{VA}=$ Total output - Total input

Total output refers to total revenue generated during the fiscal year by an organization, and Total input includes operating expenses excluding those of employees. This concept of Value Added does not treat employee-related expenditures as part of the expenses anymore. Rather, employee-related expenditures are treated as investments. While Capital employed (CE) means the tangible assets of bank, or determined by total assets minus intangible assets, the Human capital (HC) talks of the expenses made on employees such as salaries, training costs and other human related expenses and structural capital (SC) is determined by value added (VA) minus human capital (HC).

This study applies two regression models. Model 1 examines the relationship between financial performance and the aggregate measure of value added, VAIC. Model 2 examines the association 
between financial performance and the three major components of VAIC (CEE, HCE, and SCE).

The models are represented as follows:

$$
\begin{aligned}
& \mathrm{ROA}=B_{O}+B_{1}(\mathrm{HCE})+B_{2}(\mathrm{SCE})+B_{3}(\mathrm{CEE})+E \\
& \mathrm{ROA}=B_{o}+B_{1} \mathrm{VAIC}+E
\end{aligned}
$$

Where:

HCE = Human Capital Efficiency- an indicator of human capital performance determined by the ratio of the value added to human capital.

$\mathrm{CEE}=$ Capital Employed Efficiency- also an indicator of capital employed performance as determined by the ratio of the value added to capital employed.

SCE $=$ Structural Capital Efficiency- shows structural capital performance as measured by the ratio of value added and structural capital.

$\mathrm{ROA}=$ Return on assets- this is an indicator of the banks' profitability as determined by the bank's return on assets.

VAIC $=$ value added intellectual coefficient $($ VAIC $=$ HCE $+\mathrm{SCE}+\mathrm{CEE}$.

$B_{o}=$ Constant term (intercept)

$B i=$ Coefficients to be estimated

$E=$ Error term

We acknowledge that financial performance is a function of various factors, such as corporate governance mechanism, ownership structure and other company characteristics such as size and leverage. Nevertheless, it is not our intention to test the influence of these factors on profitability.

\section{Results}

Table 1 presents the descriptive statistics of the variables. The ROA ranges from 0.00 to 0.51 , with a mean of 0.072 and a standard deviation of 0.087 . The mean value of VAIC is 7.000 which indicates that VAIC is not high because the minimum value is 2.33 and the maximum is 20.57. The small standard deviation of 3.312 shows that the values are not widely dispersed 
Table 1: Descriptive Statistics

\begin{tabular}{|l|c|c|c|c|}
\hline & Mean & Std. Deviation & Minimum & Maximum \\
\hline ROA & 0.072 & 0.087 & 0.00 & 0.51 \\
\hline VAIC & 7.000 & 3.312 & 2.33 & 20.57 \\
\hline CEE & 0.099 & 0.065 & 0.03 & 0.39 \\
\hline HCE & 6.106 & 3.201 & 1.80 & 19.24 \\
\hline SCE & 0.795 & 0.100 & .044 & 0.95 \\
\hline
\end{tabular}

The mean value of capital employed efficiency (CEE) is 0.099 which means that the CEE is low because the minimum value is 0.03 and the maximum is 0.39 . Besides, there are small differences between values of CEE because the standard deviation is low (0.065). The mean value of human capital efficiency (HCE) is 6.106. The mean score is low, as the minimum and maximum values are 1.80 and 19.24, respectively.

The standard deviation is 3.201. The structural capital efficiency (SCE) ranges from 0.44 to 0.95 , with a mean score of 0.795 , and a standard deviation of 0.100. A comparison of CEE (mean $=0.099$; $\mathrm{sd}=0.065), \mathrm{HCE}($ mean $=5.483$; $\mathrm{sd}=2.593)$, and SCE $($ mean $=0.795$; sd $=0.100)$, suggests that during 2005-2007, the sample bank was generally more effective in generating value from its human capital rather than from its physical and structural assets. The standard deviation of all the variables is small. Since the number of observations is small, we performed tests of normality assumptions. Results indicate that the normality assumptions are satisfied.

Table 2 shows the results of univariate analysis using Pearson correlation. It is shown that VAIC is significantly and positively related to ROA, suggesting that the bank's financial performance is positively and significantly associated with their value creation. The higher the value of VAIC, the better the ROA banks can obtain. The analysis also suggests that HCE and CEE are significantly and positively correlated with ROA.

This finding is consistent with prior studies such as Chen et al. (2005), Kamath (2007), Mavridis and Kyrmizoglou (2005), and Yalama and Coskun (2007). On the other hand, the analysis revealed that SCE is not significantly correlated with ROA. This is consistent with prior studies such as Chen et al. (2005), Firer and Williams (2003), and Goh (2005). 
Table 2: Correlation Matrix for all dependent and independent variables $(n=54)$

\begin{tabular}{|l|c|c|c|c|}
\hline & VAIC & CEE & HCE & SCE \\
\hline ROA & $\begin{array}{c}.541 \\
(.000)^{* * *}\end{array}$ & $.883(.000)^{* * *}$ & $.719(.000)^{* * *}$ & $.230(.094)$ \\
\hline VAIC & & $0.488(.000)^{* * *}$ & $0.406(.002)^{* *}$ & $0.800(.000)^{* * *}$ \\
\hline CEE & & & $0.622(.000)^{* * *}$ & $0.274(0.45)^{*}$ \\
\hline HCE & & & & $0.210(.128)$ \\
\hline
\end{tabular}

*** Significant at the 0.01 level (2-tailed) ** Significant at the 0.05 level (2-tailed)

It is observed from Table 2 that the correlations among the three variables (CEE, HCE and SCE) are not high; the highest is 0.622, which is between CEE and HCE. Thus, multi-collinearity is not a major concern. Results of the Variance Inflation Factors (VIF) tests also show that there is no multi-collinearity problem because the VIF for each independent variable is less than 10 (Hair et al., 1998).

Table 3: Regression results of Model 1 (ROA and VAIC)

\begin{tabular}{|l|c|c|l|l|l|}
\hline & \multicolumn{2}{|l|}{$\begin{array}{l}\text { Un-standardized } \\
\text { Coefficients }\end{array}$} & $\begin{array}{l}\text { Standardized } \\
\text { Coefficients }\end{array}$ & T & sig. \\
\hline & B & Std. Error & Beta & & \\
\hline (Constant) & -.027 & .024 & & -1.140 & .260 \\
\hline VAIC & .014 & .003 & .541 & 4.644 & $.000^{* * *}$ \\
\hline Adjusted R2 $=0.280$ \\
\hline Sig. F change $=0.000$ \\
\hline
\end{tabular}

*** Significant at the 0.01 level

Tables 3 and 4 present the analysis result of the two multiple regression models. The analysis results in Table 3 reveal that VAIC is significantly and positively associated with financial performance. This result suggests that banks with greater value added, perform better in terms of return on assets.

Table 4 shows that ROA is positively correlated with CEE and HCE, suggesting that the bank's financial performance is positively associated with capital employed as well as one of the intellectual capital components, that is human capital efficiency (HCE). However, SCE has no significant association with financial performance. The major contribution on ROA is from capital 14 
employed efficiency (CEE). Except for H3, all the other three hypotheses are supported.

Table 4: Regression results of financial performance and components of VAIC

\begin{tabular}{|l|c|c|c|c|c|}
\hline & \multicolumn{2}{|c|}{$\begin{array}{c}\text { Un-standardized } \\
\text { Coefficients }\end{array}$} & $\begin{array}{c}\text { Standardized } \\
\text { Coefficients }\end{array}$ & $\mathrm{t}$ & sig. \\
\hline & $\mathrm{B}$ & STd Error & Beta & & \\
\hline (Constant) & -.057 & .041 & -1.367 & 0178 & \\
\hline CEE & .956 & .102 & .717 & 9.3 .62 & $.000^{* * *}$ \\
\hline & .009 & .003 & .278 & 3.687 & $.001 * * *$ \\
\hline & -.021 & .053 & -.024 & -0.392 & .697 \\
\hline Adjusted R2 $=0.816$ & \multicolumn{5}{l|}{} \\
\hline Sig. F change $=0.000$
\end{tabular}

*** Significant at the 0.01 level

Table 3 shows that the value added intellectual capital coefficient (VAIC) can only explain 28 percent of the variability in the bank's financial performance whereas in Table 4, it is found that the value of the adjusted R2 remarkably increases to 81.6 percent. This suggests that the three components of VAIC are better in explaining the financial performance of banks compared to the aggregate measure of VAIC. This is consistent with some of the previous studies that found R2 in Model 2 which is greater than R2 in Model 1. For example, Chen et al. (2005) shows that the adjusted $\mathrm{R} 2$ increased from 0.4684 to 0.8423 . Results of the regression analysis imply that banks that are more efficient in utilizing their tangible assets and human capital appear to have better financial returns. However, the efficiency of structural capital is not associated with the bank's financial performance. The fact that banks (as compared to other industries) do not often involve innovation capital (for example research and development, and patent) and process capital (for example organizational procedures and processes) may explain why structural capital is not associated with bank performance.

This study supports previous findings by Chen et al. (2005), Kamath (2007), Mavridis and Kyrmizoglou (2005), and Yalama and Coskun (2007) which found that there is a positive relationship 
between VAIC, HCE, and CEE and financial performance. Where structural capital is concerned, the finding is consistent with those of Chen et al. (2005), Firer and Williams (2003), and of Goh (2005) in which it was found that structural capital efficiency does not have any significant influence on the firm's financial performance.

\section{Discussion and Conclusion}

This study examined the effect and role of intellectual capitals in determining financial performance of banks in Nigeria. The intellectual capital was measured using the value added intellectual coefficient model (VAIC). The model was used to test the degree of relationship between the components of VAIC and profitability as measured by the return on assets (ROA). The VAIC model was broken into its three components to find if each of the components is also had any level of relationship with the bank's financial performance indices. This research finds that intellectual capital has a positive and significant relationship with financial performance indices of Nigeria banks. Furthermore, the value added intellectual coefficient model was segregated into its three major components and their respective relationship was also tested. It was found that financial performance is positively and significantly related with capital employed efficiency and human capital efficiency, but not with structural capital efficiency. The findings have implications for various parties in the Nigeria such as professional accounting bodies, regulators, policy makers and executors, managers of banks in Nigeria, banks shareholders, the Central Bank of Nigeria (CBN) and the Nigeria Deposit Insurance Company (NDIC). The different stakeholders can use the research findings to assign different values to the three components of capital as identified by VAIC. Also since efficient utilization of tangible capital and human capital lead to better economic performance, managers should ensure proper allocation of resources in these two capitals, as the two resources are indicated as indispensable factors that will give a bank the desired level of profitability and market share. Also professional accounting bodies in Nigeria should start developing a system of reporting intellectual capital in organisations by formulating appropriate standards to achieve such. This study therefore supports the 16 
initiatives taken by the authorities in Nigeria to capture and recognise not only on physical assets but also on human resources in enhancing firm performance and in realizing its economic vision 2020 and in the transformation agenda of the present Nigerian government.

Although structural capital does not appear significant in enhancing the profitability of banks in Nigeria, this study does not suggest that structural capital is to be ignored. This is because this study only uses one measure of profitability, which is the ROA. This study also does not classify structural capital into further components such as research and development. The importance of structural capital in enhancing firm performance could perhaps be observed in the 'other industries. Future studies may deal with these limitations.

\section{References}

Ahangar, R. G. (2011). The relationship between intellectual capitals and financial performance: An empirical investigation in an Iranian company. African Journal of Business Management, 5, 1. 4 January, 2011. http:/ / www.academicjournals.org/AJBM.

Ben-Simchon, J. (2005). Reporting of intellectual capital in research intensive SMEs (Published dissertation). The University of Inholland.

Bontis, N., Chua, W., \& Richardson S. (2000). Intellectual capital and the nature of business in Malaysia. Journal of Intellectual Capital, 1(1), 85100 .

Bornemann, M., (1999). Empirical analysis of the intellectual potential of value systems in Austria according to the VAIC.

Brennan, N., \& Connell, B. (2000). Intellectual capital: Current issues and policy implications. Journal of Intellectual Capital, 1(3), 206-240.

Chen, M. C., Cheng, S. J., \& Hwang, Y. (2005). An empirical investigation of the relationship between intellectual capital and firms' market value and financial performance, Journal of Intellectual Capital, 6 (2), 159-176.

Davenport, T. H., \& Prusak, L. (1998). Working knowledge: How organizations manage what they know. Boston:Harvard Business School Press. 
Dechow, P., (1994). Accounting earnings and cash flow as measures of firm performance the role accounting accruals. Journal of Accounting and Economics, 18 (2), 3-42.

Dechow, P., \& Skinner, D. (2000). Earnings management: Reconciling the views of academics, practitioners, and regulators. Accounting Horizons, 14 (2), 235-250.

DeFond, M., \& Park, C. (1997). Smoothing income in anticipation of future earnings. Journal of Accounting and Economics, 23, 115-139.

Drew, S. (1999). Building knowledge management into strategy: Making sense of a new perspective. Long Range Planning. 32(1), 130-136.

Edvinsson, L. (1997). Developing intellectual capital at Skandia. Long Range Planning, 30 (3), 320-373.

Edvinsson, L. \& Sullivan, P. (1996). Developing a model for managing intellectual capital. European Management Journal, 14 (4), 356-364.

Engstrom, T. E. J., Westnes, P., \& Westnes, S. F. (2003). Evaluating intellectual capital in the hotel industry. Journal of Intellectual Capital, 4 (3), 287-303.

Edvinsson L., Malone M. S. (1997). Intellectual capital: The proven way to establish your company's real value by measuring its hidden brainpower. London: Judy Piatkus.

Firer, S. \& Williams, S. M. (2003). Intellectual capital and traditional measures of corporate performance. Journal of Intellectual Capital, 4 (3), 348-360.

Goh, P. C. (2005). Intellectual capital performance of commercial banks in Malaysia. Journal of Intellectual Capital, 6 (3), 385-396.

Hair, J. F., Anderson, R. E., Tatham, R. L., \& Black, W. C., (1998). Multivariate Data Analysis (5th ed.). Upper Saddle River: Prentice-Hall.

Haniffa, M., \& Hudai, R. (2006). Corporate governance structure and performance of Malaysian listed companies. Journal of Business Finance and Accounting, 33 (7), 1034-1062.

Institute of Certified Management Accountants (ICMA), (2001). Intensive workshop in advanced strategic management accounting, ICMA, Australia.

Kamath, G. B. (2007). The intellectual capital performance of the Indian banking sector. Journal of Intellectual Capital, 8(1), 96-123. 
Kujansivu, P. \& Lonnqvist, A. (2007). Investigating the value and efficiency of intellectual capital. Journal of Intellectual Capital, 8 (2), 272287.

Lev, B. (1987). Intangibles: Management, and Reporting. Washington, DC: Brookings Institution Press.

Maria does Rosário C. \& Jorge L. V. (2005). Intellectual Capital and Value Creation: Evidence from the Portuguese Banking Industry.

Marr, B. (2004). Measuring and benchmarking intellectual capital. Journal of Intellectual Capital, 11 (6): 559-570

Mavridis, D. G. (2004). The intellectual capital performance of the Japanese banking sector. Journal of Intellectual Capital, 5 (1), 92-115.

Mavridis, D. G., \& Kyrmizoglou, P. (2005). Intellectual capital performance drivers in the Greek banking sectors. Management Research News, 28 (5), 43-62.

Miller, A., Boehlje, M., \& Dobbins, C. (2001). Key financial performance measures for farm general managers, available at: http://www.agcom.purdue.edu/AgCom/ Pubs (accessed 5 October, 2008).

Nazari, J. A., \& Herremans, I. M. (2007). Extended VAIC model: measuring intellectual capital components. Journal of Intellectual Capital, 8 (4), 595-609.

Patton, J. R. (2007). Metrics for knowledge-based project organizations, Academic Management Journal, 72(1), 33-43.

Pulic, A. (1997). The Physical and Intellectual Capital of Austrian Banks, available at: http:/ / www.vaic-on.net (accessed 5 October 2008).

Pulic, A. (1998). Measuring the performance of intellectual potential in knowledge economy, available at: http://www.measuring ip.at/ papers/Pulic/Vaictxt.vaictxt.html (accessed 4 November 2008).

Pulic, A. (2000). MVA and VAIC analysis of randomly selected companies from FTSE 250, available at: http://www.vaic-on.net/downloads/ ftse30.pdf (accessed 2 September 2008).

Pulic, A. (2002). Value creation efficiency of croatian banks 1996-2000, available at: http:/ / www.vaic-on.net (accessed 2 September 2008).

Reeds, K. (2000). The dynamics of intellectual capital (Published doctoral dissertation) The University of Connecticut. 
Riahi-Belkaoui A., (2003). Intellectual capital and firm performance of U. S. multinational firms. Journal of Intellectual Capital, 4(2), 215-226.

Roos,, J., Roos, G., Dragonetti, N., \& Edvinsson, L. (1997). Intellectual capital: Navigating the new business landscape. London: MacMillan Business.

Saint-Onge, H., (1996). Tacit knowledge: the key to the strategic alignment of intellectual capital. Strategic Leadership, 24(2), 10-14.

Saudah, S., Mike, T., \& Richard, P. (2005). The implications of intellectual capital on performance measurement and corporate performance. Available online.

Seethamraju, C., (2000). The value-relevance of trademarks (Working paper). New York City.

Stewart, T. (1997). Intellectual capital: The new wealth of organizations. New York, NY: Doubleday.

Sullivan, P. H. (2000). Value-driven intellectual capital: How to convert intangible corporate assets into market value, Toronto, Canada: John Wiley and Sons.

Teece, D. J. (2000). Managing intellectual capital: Organizational, strategic, and policy dimensions, Oxford: Oxford University Press.

Wernerfelt, B. (1984). A resource-based view of the firm. Strategic Management Journal, 5(2), 171-180.

Yalama, A. \& Coskun, M. (2007). Intellectual capital performance of quoted banks on the Istanbul stock exchange market. Journal of Intellectual Capital, 8 (2). 